\title{
Analisis Lapisan Batuan dan Potensi Air Tanah dengan Metode Geolistrik Konfigurasi Schlumberger di Kampus 2 UIN Sunan Gunung Djati Bandung
}

\author{
Rena Denya Agustina ${ }^{1 *}$, Haekal Pazha ${ }^{2}$, Muhammad Minan Chusni ${ }^{3}$ \\ 1,3 Program Studi Pendidikan Fisika UIN Sunan Gunung Djati \\ Jl. A.H Nasution No 105 Cibiru, Bandung, Jawa Barat, Indonesia \\ 2 Jurusan Fisika UIN Sunan gunung Djati \\ Jl. A.H Nasution No 105 Cibiru, Bandung, Jawa Barat, Indonesia \\ *E-mail: renadenya@uinsgd.ac.id
}

\begin{abstract}
Abstrak
Geolistrik merupakan metode yang paling sering digunakan untuk memperoleh gambaran bawah permukaan dengan kemungkinan terdapatnya air tanah dan mineral pada kedalaman tertentu. Perkiraan dengan metode ini didasarkan pada fakta bahwa material yang berbeda akan memiliki jenis resistansi yang berbeda ketika dialiri arus listrik. Tujuan dari penelitian ini adalah untuk memperkirakan sifat kelistrikan formasi batuan bawah permukaan, terutama kemampuannya untuk menghasilkan listrik atau menghambat listrik. Hasil penelitian menunjukkan bahwa di daerah yang diuji memiliki kondisi geologi lapisan tanah yang didominasi oleh tanah, pasir serta kerikil di area permukaan, sedangkan untuk kedalaman $50 \mathrm{~m}$ didominasi oleh batuan sedimen yang diiringi oleh batuan basalt dengan sedikit batuan asin di lapisan terdalam. Untuk resistivitas besar dalam kisaran nilai 3000 - 5000 $\Omega m$ menunjukkan bahwa area tersebut kurang memiliki potensi air tanah yang baik.
\end{abstract}

Kata kunci: Geolistrik, air tanah, jenis batuan, Schlumberger

\begin{abstract}
Geoelectric is the method most often used to obtain subsurface images with the possibility of groundwater and minerals at a certain depth. Estimations by means of this method are based on the fact that different materials will have different types of resistance when electrified. The purpose of this research is to estimate the electrical properties of subsurface rock formations, especially their ability to generate electricity or inhibit electricity. The results showed that the tested area had soil geological conditions which were dominated by soil, sand and gravel in the surface area, whereas for $50 \mathrm{~m}$ depth it was dominated by sedimentary rocks accompanied by basalt rocks with little saline in the deepest layer. For large resistivity in the range of $3000-5000 \Omega \mathrm{m}$ it indicates that the area has poor groundwater potential.
\end{abstract}

Keywords: Geoelectric, groundwater, rock formations, Schlumberger

\section{PENDAHULUAN}

Air merupakan sumber kehidupan bagi manusia sebagai cairan penyusun tubuh. Kandungan air pada setiap tubuh manusia bervariasi sesuai dengan usia. Kandungan air pada bayi 80 persen, orang dewasa sebesar 60 persen dan pada usia lanjut atau di atas 65 tahun sebesar 50 persen (Ekasari, 2012). Air dalam tubuh manusia berfungsi untuk menjaga keseimbangan metabolisme dan fisiologi tubuh. Disamping itu, transportasi zat - zat makanan dalam tubuh semuanya dalam bentuk larutan dengan pelarut air (Slamet, 2004). Komponen sel terbanyak dalam tubuh manusia terdiri dari air, maka jika kekurangan air, sel tubuh akan menciut dan tidak dapat berfungsi dengan baik (Depkes RI, 2006).

Melihat begitu pentingnya air bagi setiap makhluk hidup tersebut, maka sangat diperlukan sumber air untuk menunjang keberlangsungan kehidupan. Air tanah merupakan salah satu sumber air yang dapat memenuhi kebutuhan air setiap makhluk di muka bumi (Halik \& Jojok, 2008). Menurut 
Sadjab dkk. (2012) air tanah tersimpan dalam suatu wadah (akuifer), yaitu formasi geologi yang jenuh air yang mempunyai kemampuan untuk menyimpan dan meloloskan air dalam jumlah cukup dan ekonomis (Sadjab, As'ari, \& Adey, 2012). Identifikasi untuk mengetahui keberadaan lapisan pembawa air pada kedalaman tertentu, dapat menggunakan beberapa metode penyelidikan permukaan tanah, diantaranya; metode geologi, metode gravitasi, metode magnit, metode seismik, dan metode geolistrik. Dari metode-metode tersebut, metode geolistrik merupakan metode yang banyak sekali digunakan dan hasilnya cukup baik (Bisri, 1991).

Metode geolistrik dimaksudkan untuk memperoleh gambaran mengenai lapisan tanah di bawah permukaan dengan kemungkinan terdapatnya air tanah dan mineral pada kedalaman tertentu (Sedana, As'ari, \& Adey, 2015). Pendugaan geolistrik ini didasarkan pada kenyataan bahwa material yang berbeda akan mempunyai resistivitas yang berbeda apabila dialiri arus listrik. Air tanah mempunyai resistivitas yang lebih rendah daripada batuan mineral. Beberapa penelitian yang terkait dengan pendugaan geolistrik ini diantaranya; penyelidikan untuk mengetahui sebaran mineral batu bara (Azhar \& Handayani, 2004) dan penyelidikan eksplorasi air bawah tanah (Ali, Za'ari, \& Supoyo, 2003) dengan hasil bahwa lapisan batubara dan sumber air bawah tanah dapat dideteksi berdasarkan variasi resistivitasnya. Maka, secara umum tujuan dari penelitian ini adalah untuk memperkirakan sifat kelistrikan medium atau formasi batuan bawah permukaan terutama kemampuannya untuk menghantarkan atau menghambat listrik.

Metode geolistrik resistivitas adalah salah satu metode yang cukup banyak digunakan dalam dunia eksplorasi khususnya eksplorasi air tanah karena resistivitas dari batuan sangat sensitif terhadap kandungan airnya dimana bumi dianggap sebagai sebuah resistor. Metode geolistrik resistivitas adalah salah satu dari jenis metode geolistrik yang digunakan untuk mempelajari keadaan bawah permukaan dengan cara mempelajari sifat aliran listrik di dalam batuan di bawah permukaan bumi (Hendrajaya, 1990).

Metode resistivitas umumnya digunakan untuk eksplorasi dangkal, sekitar $300-500$ $\mathrm{m}$. Prinsip dalam metode ini yaitu arus listrik diinjeksikan ke alam bumi melalui dua elektroda arus, sedangkan beda potensial yang terjadi diukur melalui dua elektroda potensial. Dari hasil pengukuran arus dan beda potensial listrik, dapat diperoleh variasi nilai resistivitas listrik pada lapisan di bawah titik ukur. llustrasi garis ekipotensial yang terjadi akibat injeksi arus ditunjukkan pada dua titik arus yang berlawanan di permukaan bumi dapat dilihat pada gambar 1 .

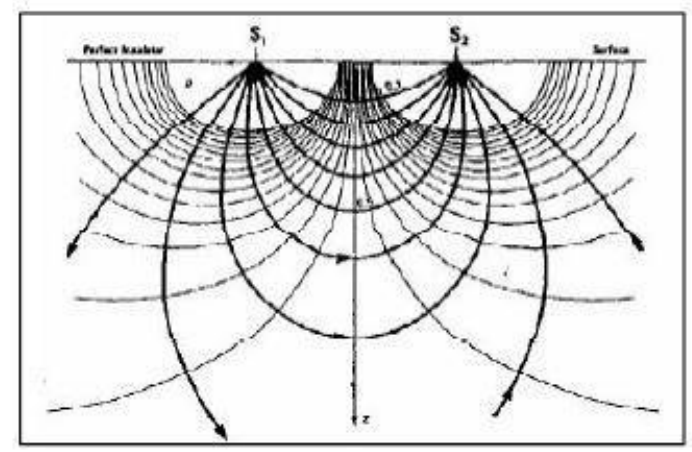

Gambar 1. Pola Aliran dan Bidang Ekipotensial

Semakin besar jarak antar elektroda menyebabkan makin dalam tanah yang dapat diukur. Ada beberapa konfigurasi untuk resistivitas dalam melakukan akuisisi data. Salah satunya adalah dengan menggunakan konfigurasi Schlumberger. Konfigurasi Schlumberger ditunjukkan pada gambar 2.

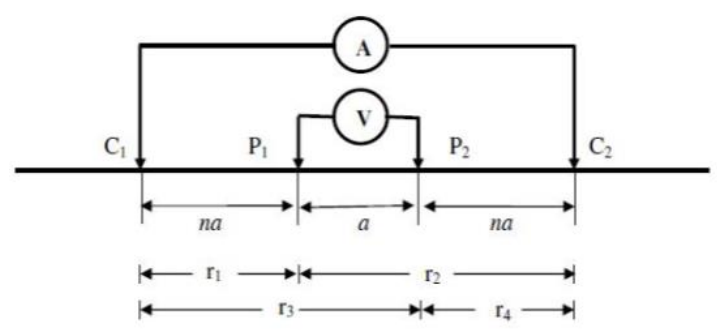

(Telford, 1990)

Gambar 2. Konfigurasi Schlumberger

Konsep perambatan listrik yang berlaku pada media homogen isotropis dengan mengukur beda potensial antara dua titik yang terjadi akibat adanya aliran arus searah melalui bawah permukaan. Untuk media terbatas (silinder,balok) berlaku : 


$$
R=\frac{\Delta V}{I}
$$

dengan $R, \Delta V$ dan I adalah tahanan listrik (ohm), beda potensial (volt), dan besar arus listrik (ampere)

Pada balok atau silinder yang homogen maka besar tahanan listrik adalah :

$$
R=\frac{\rho L}{A}
$$

dengan $L, A$ dan $\rho$ adalah panjang silinder (m), luas penampang $\left(\mathrm{m}^{2}\right)$ dan hambat jenis spesifik (ohm-meter). Sifat merambat arus listrik lebih banyak memanfaatkan sifat daya hantar jenis listrik yang berbanding terbalik dengan resistivitas, yaitu

$$
\sigma=\frac{1}{\rho}
$$

dengan $\sigma$ adalah daya hantar jenis listrik (konduktivitas) dalam satuan siemens (S) permeter

\section{Potensial listrik oleh sumber arus tunggal di permukaan}

Bila arus tunggal I diinjeksikan ke dalam bumi yang homogen isotropik dan permukaan yang dilalui arus/ merupakan ruang setengah bola $\left(2 \pi r^{2}\right)$, maka potensial $V$ di suatu titik yang berjarak $r$ dari sumber arus tunggal I adalah:

Dengan

$$
R=\frac{\rho L}{A}
$$

$A=2 \pi r^{2}$ dan $L=r$

Maka:

$$
R=\frac{\rho r}{2 \pi r^{2}}
$$

Jadi, besar potensial $V$ pada jarak $r$ adalah:

Atau

$$
V=\frac{I \rho}{2 \pi r}
$$

$$
\rho=2 \pi r \frac{V}{I}
$$

dengan $V, I, \rho$ dan $r$ adalah potensial (volt), arus listrik (ampere), resistivitas batuan (ohmmeter), dan jarak dari suatu titik ke sumber arus $(\mathrm{m})$.

\section{Faktor geometri dan konfigurasi elektroda}

Konfigurasi Wenner merupakan salah satu konfigurasi yang sering digunakan dalam eksplorasi geolistrik dengan susunan jarak spasi sama panjang $\left(r_{1}=r_{4}=a\right.$ dan $\left.r_{2}=r_{3}=2 a\right)$. Jarak antara elektroda arus adalah tiga kali jarak elektroda potensial, jarak potensial dengan titik souding-nya adalah a/2, maka jarak masing elektroda arus dengan titik soundingnya adalah $3 \mathrm{a} / 2$. Target kedalaman yang mampu dicapai pada metode ini adalah a/2. Dalam akuisisi data lapangan susunan elektroda arus dan potensial diletakkan simetri dengan titik sounding. Pada konfigurasi Wenner jarak antara elektroda arus dan elektroda potensial adalah sama. Seperti yang tertera pada gambar 3 .

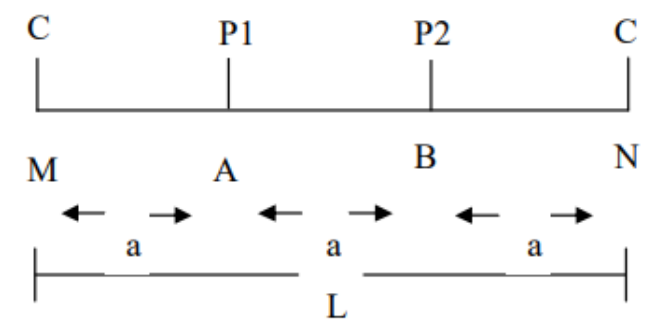

Gambar 3. Elektroda arus dan potensial pada konfigurasi Wenner.

Perbedaan letak elektroda potensial (M-N) dari letak elektroda arus (A-B) akan mempengaruhi besar medan listrik yang diukur.

Metode geolistrik resistivitas didasarkan pada anggapan bahwa bumi mempunyai sifat homogen isotropis. Dengan asumsi ini, resistivitas yang terukur merupakan tahanan jenis yang sebenarnya dan tidak tergantung pada spasi elektroda. Namun pada kenyataanya bumi tersusun atas lapisanlapisan dengan resistivitas yang berbeda-beda, sehingga potensial yang terukur merupakan pengaruh dari lapisan-lapisan tersebut. Karenanya, harga resistivitas yang diukur seolah-olah merupakan nilai resistivitas untuk satu lapisan saja resistivitas yang terukur sebenarnya adalah resistivitas semu.

$$
\rho=2 \pi\left(\left(\frac{1}{r_{1}}-\frac{1}{r_{2}}\right)-\left(\frac{1}{r_{3}}-\frac{1}{r_{4}}\right)\right)^{-1} \cdot \frac{\Delta V}{I}
$$

atau

dengan:

$$
\rho=K \frac{\Delta V}{I}
$$

$$
K=2 \pi\left(\left(\frac{1}{r_{1}}-\frac{1}{r_{2}}\right)-\left(\frac{1}{r_{3}}-\frac{1}{r_{4}}\right)\right)^{-1}
$$

Dimana $\mathrm{K}$ adalah faktor geometri yaitu: besaran koreksi letak kedua elektroda potensial 
terhadap letak elektroda arus

\section{METODE}

Penelitian ini dilakukan di belakang gedung Pascasarjana Kampus II UIN Sunan Gunung Djati Bandung. Lokasi penelitian dapat dilihat pada gambar 3. Sedangkan penentuan lintasan dan titik pengukuran geolistrik dilakukan di belakang Gedung Pasca Sarjana UIN Sunan Gunung Djati Bandung (656'20.5"S 10742'23.1"). Lintasan dan titik pengukuran geolistrik dalam penelitian ini ditunjukkan pada Gambar 4. Pengukuran geolistrik yang diterapkan pada penelitian ini adalah geolistrik sounding (vertikal) konfigurasi Schlumberger. Pengukuran yang dilakukan sebanyak 7 kali pengambilan data dengan jarak antar elektroda $A B$ terdekat sepanjang $3 \mathrm{~m}$ yang terus diperjauh hingga mencapai jarak terjauh $A B$ sepanjang $50 \mathrm{~m}$, dengan konfigurasi Schlumberger jarak MN yang ditentukan pada data hasil pengamatan selanjutnya.

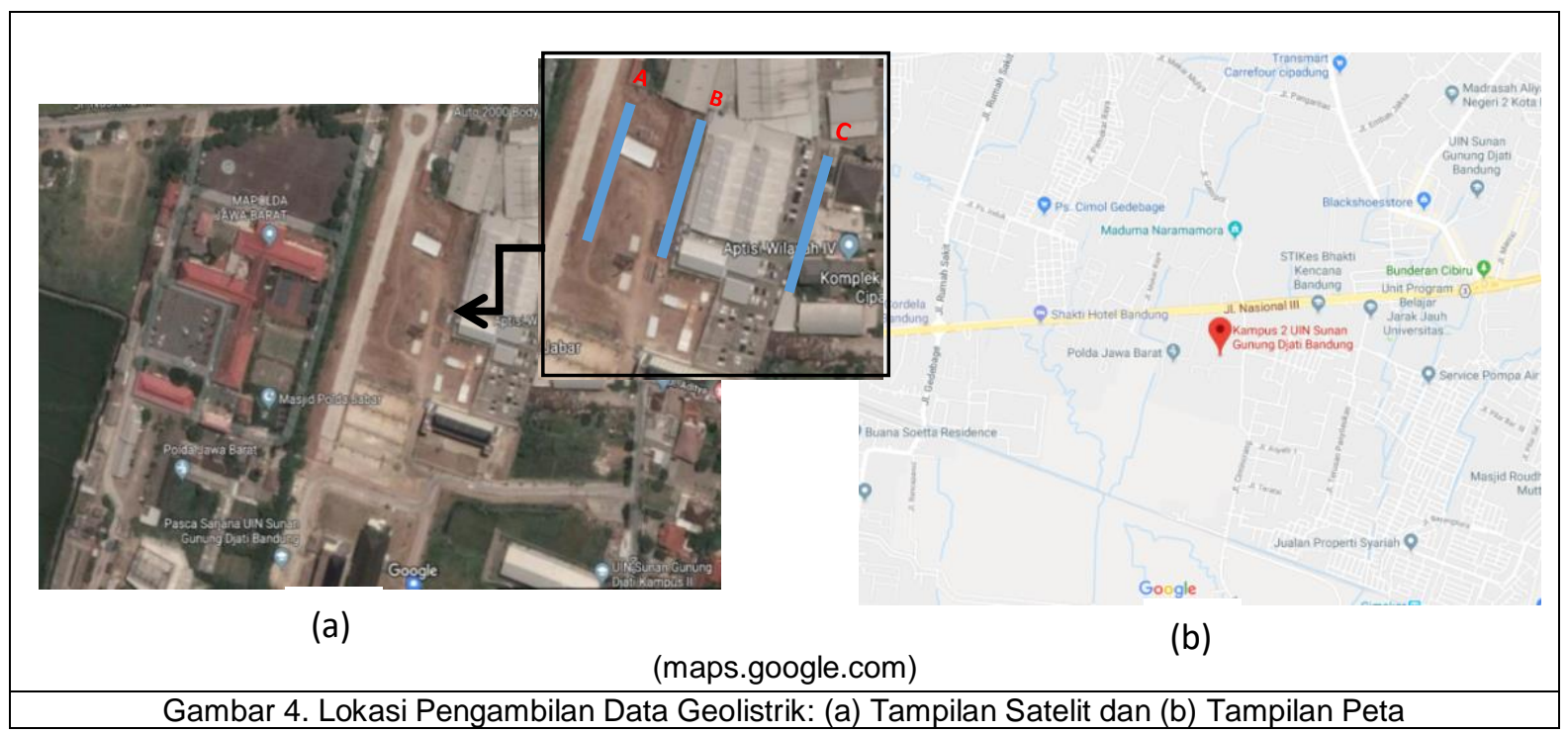

\section{HASIL DAN PEMBAHASAN}

Berdasarkan percobaan yang telah dilakukan di belakang gedung Pascasarjana Kampus II UIN Sunan Gunung Djati Bandung, didapatkan data hasil pengamatan sebagai berikut.

Tabel 1. Data Pengamatan Geolistrik Lintasan A

\begin{tabular}{ccccc}
\hline $\mathrm{AB} / 2$ & $\mathrm{MN}$ & $\mathrm{V}(\mathrm{mV})$ & $\mathrm{I}(\mathrm{mA})$ & $\rho(\Omega m)$ \\
\hline 1,5 & 1 & 158,4 & 0,70 & 1422 \\
\hline 5 & 3 & 154,5 & 0,43 & 8179 \\
\hline 10 & 6 & 153,2 & 0,40 & 18249 \\
\hline 20 & 12 & 166,4 & 0,43 & 36877 \\
\hline 30 & 20 & 148,6 & 0,76 & 24571 \\
\hline 40 & 25 & 154,2 & 0,85 & 32913 \\
\hline 50 & 30 & 149,2 & 0,87 & 40856 \\
\hline
\end{tabular}

Tabel 2. Data Pengamatan Geolistrik Lintasan B

\begin{tabular}{ccccc}
\hline $\mathrm{AB} / 2$ & $\mathrm{MN}$ & $\mathrm{V}(\mathrm{mV})$ & $\mathrm{I}(\mathrm{mA})$ & $\rho(\Omega m)$ \\
\hline 1,5 & 1 & 161,4 & 0,70 & 1448,72 \\
\hline 5 & 3 & 161,6 & 0,46 & 6621,93 \\
\hline 10 & 6 & 161,8 & 0,49 & 12448,40 \\
\hline 20 & 12 & 161,4 & 0,50 & 24338,55 \\
\hline 30 & 20 & 161,6 & 0,80 & 25384,07 \\
\hline 40 & 25 & 161,8 & 0,92 & 27625,53 \\
\hline 50 & 30 & 160,9 & 0,88 & 22976,47 \\
\hline
\end{tabular}

Tabel 3. Data Pengamatan Geolistrik Lintasan C

\begin{tabular}{ccccc}
\hline $\mathrm{AB} / 2$ & $\mathrm{MN}$ & $\mathrm{V}(\mathrm{mV})$ & $\mathrm{I}(\mathrm{mA})$ & $\rho(\Omega m)$ \\
\hline 1,5 & 1 & 164,3 & 0,67 & 1541 \\
\hline 5 & 3 & 160,2 & 0,52 & 7340 \\
\hline 10 & 6 & 156,2 & 0,48 & 15505 \\
\hline 20 & 12 & 149,8 & 0,52 & 27452 \\
\hline 30 & 20 & 156,5 & 0,78 & 25213 \\
\hline
\end{tabular}




\begin{tabular}{ccccc}
\hline $\mathrm{AB} / 2$ & $\mathrm{MN}$ & $\mathrm{V}(\mathrm{mV})$ & $\mathrm{I}(\mathrm{mA})$ & $\rho(\Omega m)$ \\
\hline 40 & 25 & 157,8 & 0,90 & 31810 \\
\hline 50 & 30 & 163,4 & 0,87 & 44745 \\
\hline
\end{tabular}

Nilai $\rho$ didapatkan pada setiap percobaan dengan menggeser elektroda $A B$ yang digunakan sebagai aliran injeksi arus listrik dan elektroda MN yang digunakan untuk membaca tegangan listrik yang terdapat pada tanah. Berdasarkan permindahan setiap elektroda tersebut, terjadi peningkatan nilai rho yang meningkat seiring dengan pertambahan jarak elektroda $A B$ dan MN. Hubungan antara peningkatan nilai resistivitas $(\rho)$ terhadap jarak elektroda $A B$ digambarkan sebagai berikut.

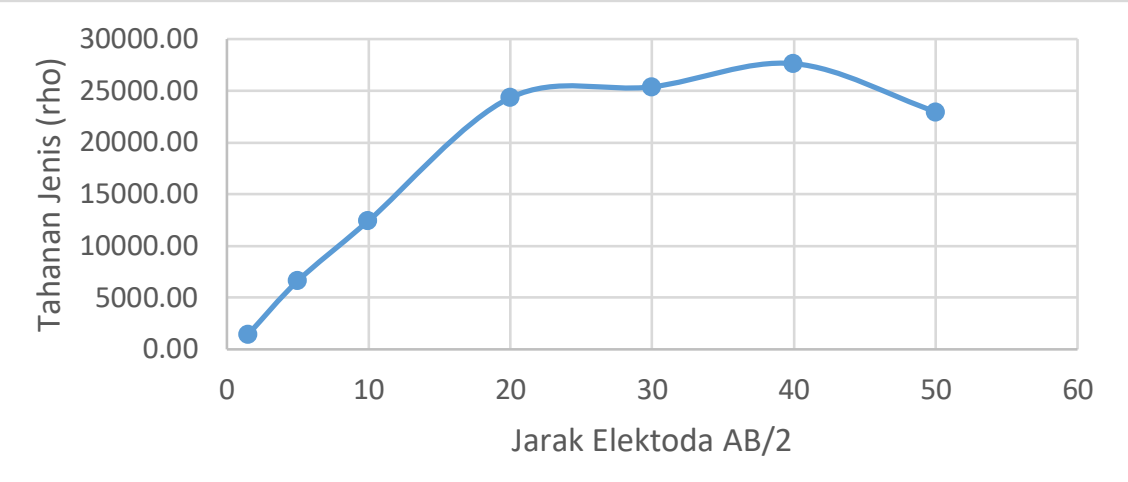

Grafik 1. Rata-rata Hubungan Antara Nilai Resistivitas $(\rho)$ Terhadap Jarak Elektroda AB/2 Pada Ketiga Lintasan.

Berdasarkan data tersebut, terlihat bahwa kenaikan nilai resistivitas $(\rho)$ mengalami perbedaan pada setiap titik pengukuran. Bentuk grafik yang dihasilkan dari data percobaan geolistrik yang menggunakan konfigurasi Schlumberger menghasilkan beberapa bentuk kurva yang dijadikan sebagai suatu acuan yaitu sebagai berikut.
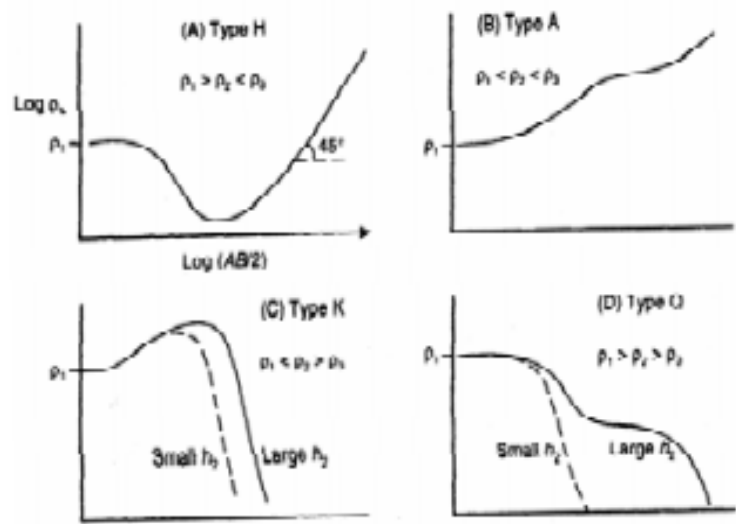

Gambar 4. Kurva-Kurva Bantu Dalam Metode Penyamaan Kurva Schlumberger

Dengan keterangan pada bentuk umum masing-masing kurva adalah sebagai berikut. Kurva bantu $\mathrm{H}$ menunjukan harga $\rho$ minimum dan adanya variasi 3 lapisan dengan $\rho 1>\rho 2<$ $\rho 3$; Kurva bantu A menunjukkan pertambahan harga $\rho$ dan variasi lapisan dengan $\rho 1<\rho 2<$ p3;

Kurva bantu K menunjukan harga $\rho$ maksimum dan variasi lapisan dengan $\rho 1<\rho 2>\rho 3$; dan Kurva bantu $Q$ menunjukan penurunan harga $\rho$ yang seragam : $\rho 1>\rho 2>\rho 3$

Berdasarkan grafik kurva bantu metode penyamaan kurva Schlumberger diatas menunjukan bahwa grafik yang dihasilkan pada data yang digambarkan oleh grafik 1 memiliki kesesuaian dengan grafik tipe $\mathrm{K}$ pada grafik 2 diatas yang berarti harga $\rho$ maksimum dan variasi lapisan dengan $\rho 1<\rho 2>\rho 3$.

Kemudian, untuk menganalisis nilai resistivitas pada setiap lapisan batuan serta mengetahui jenis - jenis batuan pada setiap lapisan tanah dengan kedalaman tertentu, dilakukan dengan mengolah data hasil percobaan menggunakan software IPI2WIN. Hasil pengolahan data pseudosection (Pseudoseksi, juga disebut diagram fase kesetimbangan, adalah jenis diagram fase yang menunjukkan bidang stabilitas kumpulan mineral ekuilibrium yang berbeda untuk komposisi batuan massal tunggal) berupa distribusi resistivitas sebenarnya terhadap penampang melintang di bawah permukaan tanah. Hasil pengolahan data yang diperoleh berupa penampang resistivitas yang 
menggambarkan nilai distribusi lapisan bawah permukaan tanah pada masing-masing titik kedalaman lapisan tanah. Pada penampang resistivitas tersebut, perubahan nilai resistivitas dinyatakan dalam bentuk citra warna yang berbeda-beda dengan kedalaman atau ketebalan lapisan tertentu sesuai dengan nilai resistivitasnya. Hasil distribusi resistivitas pada setiap kedalaman tanah ini atau distribusi resistivitas berdasarkan penampang vertikal ini ditunjukan oleh Gambar 6.

Berdasarkan Gambar 6 distribusi nilai resistivitas pada setiap lapisan kedalaman tanah, menunjukkan setiap lapisan tanah memiliki nilai resistivitas yang berbeda. Nilai resistivitas ini juga dapat menunjukan jenis batuan yang ada di dalamnya. Penentuan jenis batuan berdasarkan nilai resistivitas ini dimuat dalam tabel 4.
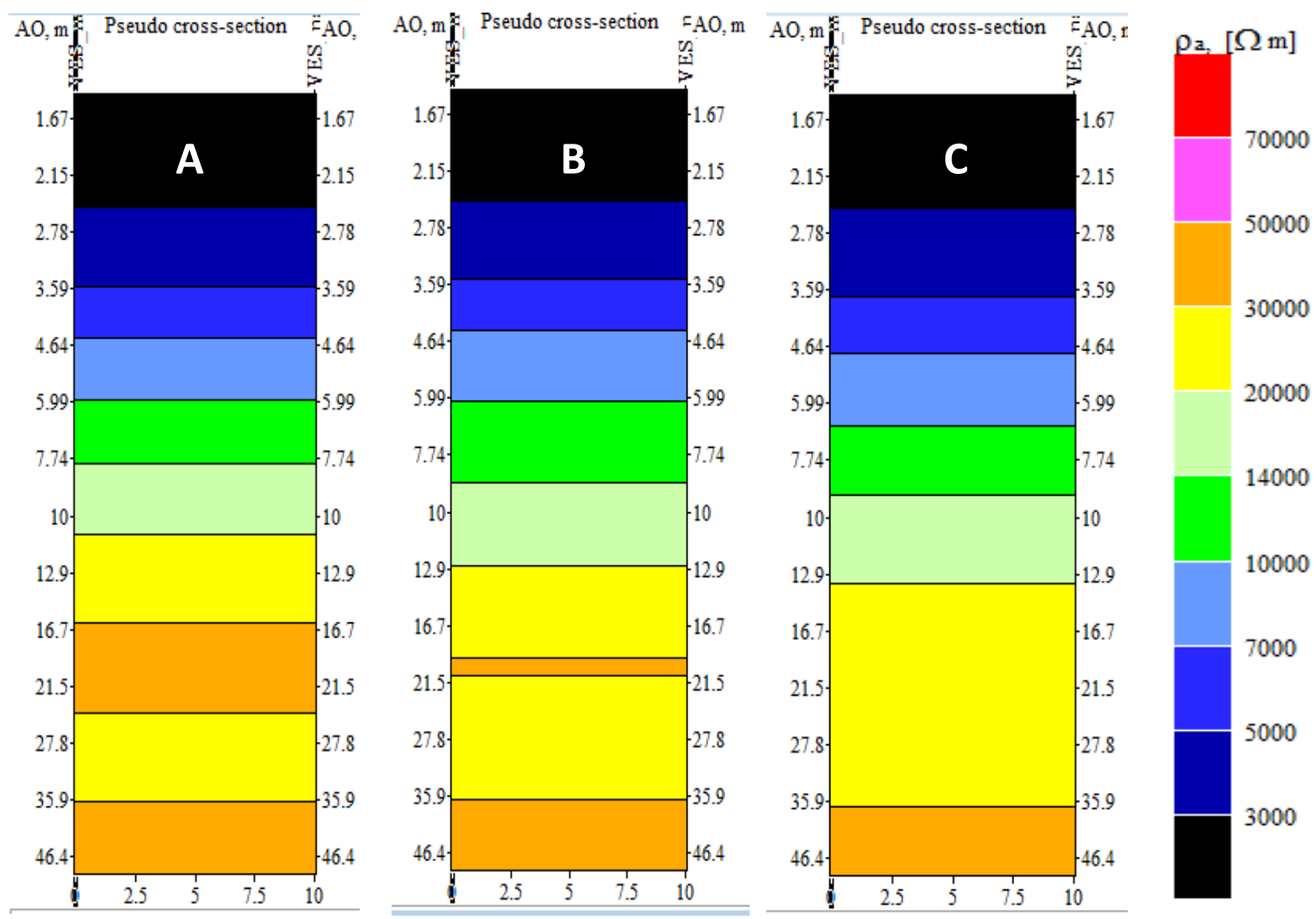

Gambar 6. Distribusi Nilai Resistivitas Pada Setiap Lapisan Kedalaman Tanah

Tabel 4 Jenis batuan berdasarkan nilai resistivitasnya

\begin{tabular}{ccccc}
\hline No & Kedalaman $(\mathrm{m})$ & $\begin{array}{c}\text { Nilai Resistivitas } \\
(\Omega \mathrm{m}) \times 10^{3}\end{array}$ & Jenis Lapisan Tanah/Batuan & Indeks Warna \\
\hline 1 & $0,00-2,50$ & $<3$ & $\begin{array}{c}\text { Lapisan ini didominasi oleh tanah, } \\
\text { kerikil, dan lapisan pasir }\end{array}$ & Hitam \\
\hline 2 & $2,50-3,50$ & $3-5$ & $\begin{array}{c}\text { Batuan sedimen yang terutama } \\
\text { terdiri dari mineral berukuran pasir } \\
\text { atau butir-butir batuan }\end{array}$ & Biru lebih tua \\
\hline 3 & $3,50-4,50$ & $5-7$ & $\begin{array}{c}\text { Batuan sedimen yang terutama } \\
\text { terdiri dari mineral berukuran pasir } \\
\text { atau butir-butir batuan }\end{array}$ & Biru tua \\
\hline
\end{tabular}




\begin{tabular}{ccccc}
\hline No & Kedalaman $(\mathrm{m})$ & $\begin{array}{c}\text { Nilai Resistivitas } \\
(\Omega \mathrm{m}) \times 10^{3}\end{array}$ & Jenis Lapisan Tanah/Batuan & Indeks Warna \\
\hline 4 & $4,50-6,00$ & $7-10$ & $\begin{array}{c}\text { Batuan sedimen yang disertai } \\
\text { batuan basal dan batuan pasir }\end{array}$ & Biru muda \\
\hline 5 & $6,00-8,50$ & $10-14$ & $\begin{array}{c}\text { Batuan sedimen yang disertai } \\
\text { batuan basal dan batuan pasir }\end{array}$ & Hijau tua \\
\hline 6 & $8,50-12,80$ & $14-20$ & $\begin{array}{c}\text { Batuan sedimen yang disertai } \\
\text { batuan basal dan batuan pasir }\end{array}$ & Hijau muda \\
\hline 7 & $12,80-20,00$ & $20-30$ & $\begin{array}{c}\text { Batuan sedimen yang disertai } \\
\text { batuan basal dan batuan pasir }\end{array}$ & Kuning \\
\hline 8 & $20,00-21,40$ & $30-50$ & $\begin{array}{l}\text { Batuan sedimen yang disertai } \\
\text { batuan basal dan batuan pasir }\end{array}$ & Orange \\
\hline 9 & $21,40-36,00$ & $50-70$ & $\begin{array}{l}\text { Batuan sedimen yang disertai } \\
\text { batuan basal dan batuan pasir }\end{array}$ & Kuning \\
\hline 10 & $36,00-46,30$ & $70-100$ & $\begin{array}{c}\text { Batuan sedimen yang disertai } \\
\text { batuan basal dan batuan pasir }\end{array}$ & Orange \\
\hline 11 & $45,30-50,00$ & $>100$ & $\begin{array}{c}\text { Batuan garnit yang disertai dengan } \\
\text { batu gamping hingga batuan garam }\end{array}$ & Merah muda \\
\hline & & & & \\
\hline
\end{tabular}

Berdasarkan data di atas ditinjau dari nilai resistivitasnya menunjukan bahwa sebagian besar batuan didominasi oleh pasir mau pun batuan sedimen yang terdiri dari mineral berukuran pasir dengan keseluruhan nilai resistivitas yang berada pada rentang 300 $100000 \Omega \mathrm{m}$. Dengan nilai resistivitas yang tinggi tersebut mengindikasikan bahwa di daerah belakang Gedung Pascasarjana kampus II UIN Sunan Gunung Djati Bandung kurang terdapat air tanah yang dapat dimanfaatkan sebagai sumber air atau dengan kata lain tidak direkomendasikannya tempat tersebut untuk dilakukan pengeboran sumber air karena lapisan ini kurang mempunyai sifat sebagai lapisan pembawa air.

\section{KESIMPULAN}

Berdasarkan hasil penyelidikan di Kawasan Kampus 2 UIN Sunan Gunung Djati Bandung tepatnya dibekakang Gedung pasca sarjana, maka dapat disimpulkan bahwa, secara geologis batuan dilokasi penelitian tersebut didominasi oleh tanah dan pasir serta kerikil untuk bagian permukaannya, tetapi untuk bagian dalamnya hingga kedalaman $50 \mathrm{~m}$ didominasi oleh batuan sedimen yang disertai oleh batuan basal dengan sedikit batuan garam pada lapisan terdalamnya. Lalu, untuk tujuan pengeboran air tanah pada daerah tersebut kurang direkomendasikan, karena dilihat dari nilai resistivitas batuan yang besar yang mengindikasikan bahwa jenis lapisan pada daerah tersebut kurang mempunyai sifat sebagai lapisan pembawa air.

\section{DAFTAR PUSTAKA}

Ali, M., Za'ari, \& Supoyo. (2003). Eksplorasi, eksploitasi Sumber Daya Mineral Air Bawah Tanah : Studi Kasus Di Kawasan Industri Pasuruan Jawa Timur. Proceedings of Joint The 32 nd IAGI dan The 28 th HAGI Annual Convention and Exhibition.

As'ari. (2011). Pemetaan Air Tanah Di Kabupaten Jeneponto Dengan Metode Geolistrik. Jurnal Sainstek, 1-7. http://ecampus.iainbatusangkar.ac.id/ojs/in dex.php/sainstek/article/view/29

Azhar, \& Handayani, G. (2004). "Penerapan Metode Geolistrik Konfigurasi Schlumberger untuk Penentuan Tahanan Jenis Batubara. Jurnal Natur Indonesia, 122-126.

Bisri, M. (1991). Aliran Air Tanah. Malang. Malang: Fakultas Teknik Universitas Brawijaya. 
Depkes Rl. (2006). Pedoman Pelaksanaan Penyelenggaraan Hygiene SanitasiDepot Air Minum. Jakarta: Ditjen PP dan PL.

Ekasari, E. (2012). Akibatnya Kekurangan Minum Air Putih. Jakarta: Detik.com.

Halik, G., \& Jojok, W. S. (2008). Pendugaan Potensi Air Tanah Dengan Metode Geolistrik Konfigurasi Schlumberger Di Kampus Tegal Boto Universitas Jember. Media Teknik Sipil, 8(2), 109-114.

Haryani, F. F., Amaliah, R., Fitrasari, D., \& Viridi, S. (2016). Konsep fisika dalam gerak permainan roket air. Seminar Nasional Pendidikan Sains (pp. 245-254). Surakarta: Universitas Sebelas Maret.

Hendrajaya, L. (1990). Pengukuran Resistivitas Bumi pada Satu Titik di Medium Tak Hingga. Bandung: Laboratorium Fisika

Sadjab, B., As'ari, \& Adey, T. (2012). Pemetaan Akuifer Air Tanah di Kecamatan Prambanan Kabupaten Sleman Daerah Istimewa Yogyakarta Dengan Metode Geolistrik Tahanan Jenis. Jurnal MIPA UNSRAT Online, 1(1), 37-44..

Sedana, D., As'ari, \& Adey, T. (2015). Pemetaan Akuifer Air Tanah Di Jalan Ringroad Kelurahan Malendeng Dengan Menggunakan Metode Geolistrik Tahanan Jenis. Jurnal IImiah Sains, 15(1), 33-37..

Slamet, J. (2004). Kesehatan Lingkungan. Yogyakarta: Gajah Mada University Press.

Telford, G. (1990). Applied Geophysics. London: Cambridge University Press.

Wiyono, K. (2009). Model Pembelajaran Multimedia Interaktif Relativitas Khusus untuk Meningkatkan Penguasaan Konsep, Keterampilan Generik Sains Siswa SMA. Jurnal Penelitian Pendidikan, 3(1), 21-30. 